\title{
Efficiency Analysis and Smoked Fish Business Development Strategy in Kendal Regency
}

\author{
Hadi Sasana ${ }^{1}$, Ivo Novitaningtyas ${ }^{2 *}$, and Yuliani Setyaningsih ${ }^{3}$ \\ ${ }^{1}$ Faculty of Economic and Business, Diponegoro University, Semarang, Indonesia \\ ${ }^{2}$ Faculty of Economic, Tidar University, Magelang, Indonesia \\ ${ }^{3}$ Faculty of Public Health, Diponegoro University, Semarang, Indonesia
}

\begin{abstract}
MSME was proven to have a positive impact on economic growth, thus MSME's business needs to become sustainable. MSME's business sustainability is determined by the MSME's ability to manage their profit efficiency and develop their business strategy. This study aims to examine the profit efficiency of the smoked fish business as one of MSMEs and the BUMDes development strategy in coastal community Tambaksari, Kendal Regency. The quantitative approach was conducted in this study. Primary data from 30 smoked fish entrepreneurs and 3 key person of BUMDes were collected by interview and questionnaire, then analyzed with Stochastic Translog Profit Frontier Analysis and Analytic Hierarchy Process (AHP). The results show that the efficiency of the smoked fish business still low due to age and education of the human resources. In addition, the propose strategies for develop the BUMDes are managerial training, comparative studies, and coordination with stakeholders in improving performance. The implication of this study is useful for smoked fish entrepreneurs and BUMDes to increase profit efficienct and develop strategy in order to make the business sustainable.
\end{abstract}

\section{Introduction}

MSMEs (Micro, Small and Medium Enterprises) are one of the pillars of the Indonesian economy. This was proven when Indonesia was able to face the economic crisis in 1997/1998. The big companies that were expected to survive at that time turned out to be those that failed. On the other hand, MSMEs have actually become the driving force of the economy in the midst of a crisis [44]. MSMEs are a small community economic sector with local scale, local resources, and simple production processes whose products are sold locally. The role of MSMEs for the economy includes supporting national economic growth, distributing development results, and creating jobs [41].

The Indonesian Ministry of Cooperatives and MSMEs (2018) stated that in 2017 MSMEs had a share of around $99.99 \%$ (62.9 million units) of the total business actors in Indonesia, while large businesses were only $0.01 \%$ or around 5400 units. Micro Enterprises absorb around 107.2 million workers (89.2\%), Small Businesses 5.7 million (4.74\%) and

\footnotetext{
* Corresponding author: ivo.novitaningtyas@untidar.ac.id
} 
Medium Enterprises 3.73 million (3.11\%), while Large Enterprises absorb around 3.58 million people. This means that combined, MSMEs absorb around 97\% of the national workforce, while large businesses only absorb about 3\% of the total national workforce. This condition supports the previous researcher who explains the existence of MSMEs is very important because it is beneficial for the economy [41].

Because of the importance of MSMEs, it is necessary to analyze the performance of MSMEs. It is also necessary to identify the factors that affect their performance and strategies for developing these MSMEs. In this study, performance can be analyzed by measuring the efficiency of SMEs, as well as looking at the factors that cause the inefficiency of these MSMEs [19]. The MSME development strategy can be analyzed using the Analytical Hierarchy Process (AHP) [40].

Many studies related to business efficiency have been done by previous researchers. The previous study including in the agricultural sector [1, 5, 23-24, 26, 31-32, 34, 37, 43]. Livestock Sector [10, 33]. Banking sector [9, 14, 20], and also MSME Sector [10, 33]. However, research that combines efficiency studies and strategy development in MSMEs, especially the smoked fish business, has not been widely carried out.

The object of this study is MSME smoked fish business in Tambaksari Village. Tambaksari village, as a "minapolitan" village, recorded 168 ponds/ponds with a fish income of 547.00 tons/year [38]. In addition, Tambaksari Village is supported by processing and marketing activities for fish cultivation. In the management and marketing of fish farming products, it is still limited to fish processing and sold or marketed in highland areas such as Sukorejo, Sumowono, to the Wonosobo area. Tambaksari Village can be used as a model in terms of fish cultivation as evidenced by receiving the Regent awards in 2014 Pioneer and driving fish cultivator; Best Fish Cultivator in Central Java Province 2012; The best Cultivators and the best Farmers at District Level. Kendal 2010; and Rank 2 of the 2013 National Aquaculture Institution. This study aims to analyze the efficiency of profits from the smoked fish business in Tambaksari Village Kendal, the factors that influence inefficiency and strategies in the development of BUMDes Tambaksari. Thus, the results of this study are expected to provide benefits for business owners and BUMDes in developing their business. Thus, MSMEs in Balesari Village can provide benefits for the economy.

\section{Literature Review}

There are several techniques commonly used in estimating efficiency values, such as Stochastic Frontier Analysis (SFA) as a parametric approach in which the production function is estimated statistically. The hypothesis of this approach can be tested statistically , and the relationship between input and output follows the form of the function used [19]. The concept of profit efficiency is better than the concept of cost efficiency for evaluating the company's overall performance because it collects errors from outputs and inputs [14]. There are two fundamental challenges in earnings efficiency [28]. First, the observed profit can be positive, negative, or zero, so that efficiency measures in the form of ratios have unclear results. Second, the price data obtained may be unreliable due to bias in the context of imperfectly competitive markets, resulting in difficulty in which prices to use in the calculations. In [16] states how to anticipate the negative number of company losses in the translog model, using censorship which is proven to increase the stability of the efficiency value. So that it still obtains a discriminatory value from the results without losing precision. 


\section{Method}

This study aims to determine the efficiency and the determinants of the efficiency of MSMEs for the smoked fish business in Tambaksari Village, Kendal Regency, and the priority strategies for developing BUMDEs that accommodate these SMEs. The respondents were three key persons and 30 MSMEs. The analysis used in this study is as follows: (1) Stochastic Translog Profit Frontier Analysis to measure the efficiency level of MSMEs and determine the factors that affect the level of inefficiency, and also (2) Analytic Hierarchy Process (AHP) for determining BUMDes development strategy.

\subsection{Stochastic Translog Profit Frontier Analysis}

$$
\begin{aligned}
& \pi_{i}=f\left(y_{i}, w_{i}\right) \operatorname{ecp}\left(v_{i}\right) \exp \left(-u_{i}\right) ; i=1,2,3, \ldots, N S M E \\
& \operatorname{Ln}\left[\frac{\pi}{w_{4}}+\left|\frac{\pi^{m i n}}{w_{4}}+1\right|\right]= \alpha_{0}+\alpha_{1} \operatorname{Ln} Y_{1}+\alpha_{2} \operatorname{Ln}\left(\frac{w_{1}}{w_{4}}\right)+\alpha_{3} \operatorname{Ln}\left(\frac{w_{2}}{w_{4}}\right)+\alpha_{4} \operatorname{Ln}\left(\frac{w_{3}}{w_{4}}\right)+ \\
& \alpha_{5} \frac{1}{2}\left(\operatorname{Ln} Y_{1}\right)^{2}+\alpha_{6} \operatorname{Ln}\left(\frac{w_{1}}{w_{4}}\right)+\alpha_{7} \operatorname{Ln}\left(\frac{w_{1}}{w_{4}}\right)+\operatorname{Ln}\left(\frac{w_{2}}{w_{4}}\right)+\alpha_{8} \operatorname{Ln}\left(\frac{w_{1}}{w_{4}}\right) * \\
& \operatorname{Ln}\left(\frac{w_{3}}{w_{4}}\right)+\alpha_{9} \frac{1}{2}\left(\operatorname{Ln}\left(\frac{w_{3}}{w_{4}}\right)\right)^{2}+\alpha_{10} \operatorname{Ln}\left(\frac{w_{2}}{w_{4}}\right) * \operatorname{Ln}\left(\frac{w_{3}}{w_{4}}\right)+\alpha_{11} \operatorname{Ln} Y_{1} * \\
& \operatorname{Ln}\left(\frac{w_{1}}{w_{4}}\right)+\alpha_{12} \operatorname{Ln} Y_{1} * \operatorname{Ln}\left(\frac{w_{2}}{w_{4}}\right)+\alpha_{13} \operatorname{Ln} Y_{1} * \operatorname{Ln}\left(\frac{w_{3}}{w_{4}}\right)+e
\end{aligned}
$$

Where $\pi_{i}$ is MSME i profit, yi is MSME output, wit is input price, vit is random error, and uit is inefficiency.

\subsection{Analytic Hierarchy Process (AHP)}

The steps in AHP [39]: (1). Determining Criteria, (2) Determining the Hierarchical structure, criteria, sub-criteria, and alternatives, (3) Create a pairwise comparison matrix (pairwise comparison matrix) by comparing the weights between criteria, sub-criteria and alternatives with a weighting scale of 1-9 [40], (4) Calculating the eigenvalues and eigenvectors of each pairwise comparison matrix, (5) Test consistency by looking for Consistency Index (CI) and Consistency Ratio (CR), and (6) Combine the scores of all key persons and combine the relative weights of the elements in each level to determine the overall score of each alternative.

\section{Result and Discussion}

\subsection{Profit Efficiency Analysis Result}

The calculation results of the translog model show that the age coefficient has a positive and significant value. This indicates that increasing age will reduce the efficiency value of MSMEs for processing and smoking. These results are in line with research from [43] that the older the farmer, the more inefficiency he does. [35] also stated that the older the company, the greater the inefficiency. Age here is also in line with the age of the company because the respondents are MSMEs (privately owned and inherited). [8, 15] Find that firm age can have a positive effect on efficiency. [42], found that firm age can also be negatively correlated with efficiency. 
Table 1. Maximum Likelihood Estimated of Profit Frontier Function.

\begin{tabular}{|l|c|c|c|c|}
\hline \multicolumn{1}{|c|}{ Variabel } & Parameter & Coefficient & $\begin{array}{c}\text { standard- } \\
\text { error }\end{array}$ & t-ratio \\
\hline Constanta & $\alpha_{0}$ & 43.313 & 0.967 & $44.807^{*}$ \\
\hline $\mathrm{LnY}_{1}$ & $\alpha_{1}$ & 1.740 & 0.171 & $10.203^{*}$ \\
\hline $\mathrm{Ln}\left(\mathrm{W}_{1} / \mathrm{W}_{4}\right)$ & $\alpha_{2}$ & -24.924 & 0.466 & $-53.453^{*}$ \\
\hline $\mathrm{Ln}\left(\mathrm{W}_{2} / \mathrm{W}_{4}\right)$ & $\alpha_{3}$ & -6.065 & 0.923 & $-6.572^{*}$ \\
\hline $\mathrm{Ln}\left(\mathrm{W}_{3} / \mathrm{W}_{4}\right)$ & $\alpha_{4}$ & -0.490 & 0.899 & -0.545 \\
\hline $1 / 2(\mathrm{LnY})^{2}$ & $\alpha_{5}$ & -18.798 & 0.886 & $-21.210^{*}$ \\
\hline $1 / 2 \mathrm{Ln}\left(\mathrm{W}_{1} / \mathrm{W}_{4}\right)$ & $\alpha_{6}$ & 48.223 & 0.897 & $53.778^{*}$ \\
\hline $\mathrm{Ln}\left(\mathrm{W}_{1} / \mathrm{W}_{4}\right) * \mathrm{Ln}\left(\mathrm{W}_{2} / \mathrm{W}_{4}\right)$ & $\alpha_{7}$ & 0.086 & 0.054 & 1.600 \\
\hline $\mathrm{Ln}\left(\mathrm{W}_{1} / \mathrm{W}_{4}\right) * \mathrm{Ln}\left(\mathrm{W}_{3} / \mathrm{W}_{4}\right)$ & $\alpha_{8}$ & -0.107 & 0.014 & $-7.469^{*}$ \\
\hline $1 / 2\left(\mathrm{Ln}\left(\mathrm{W}_{2} / \mathrm{W}_{4}\right)\right)^{2}$ & $\alpha_{9}$ & -0.753 & 0.286 & $-2.636^{*}$ \\
\hline $\mathrm{Ln}\left(\mathrm{W}_{2} / \mathrm{W}_{4}\right) * \mathrm{Ln}\left(\mathrm{W}_{3} / \mathrm{W}_{4}\right)$ & $\alpha_{10}$ & -0.375 & 0.220 & -1.703 \\
\hline $\mathrm{LnY} * \mathrm{Ln}\left(\mathrm{W}_{1} / \mathrm{W}_{4}\right)$ & $\alpha_{11}$ & 0.037 & 0.010 & $3.787^{*}$ \\
\hline $\mathrm{LnY} * \mathrm{Ln}\left(\mathrm{W}_{2} / \mathrm{W}_{4}\right)$ & $\alpha_{12}$ & 0.247 & 0.061 & $4.064^{*}$ \\
\hline $\mathrm{LnY} * \mathrm{Ln}\left(\mathrm{W}_{3} / \mathrm{W}_{4}\right)$ & $\alpha_{13}$ & 0.102 & 0.058 & 1.761 \\
\hline \multicolumn{1}{|c|}{ Age } & $\mathrm{Z}_{1}$ & 0.013 & 0.002 & $5.404^{*}$ \\
\hline Education $\left._{2}\right)$ & $\mathrm{Z}_{2}$ & -0.879 & 0.273 & $-3.217^{*}$ \\
\hline $\mathrm{Number}$ of family & -0.095 & 0.086 & -1.099 \\
\hline
\end{tabular}

While the variable coefficient of Education has a negative sign and is significant, this indicates that the more educated, the more efficient it will be. These results are in line with the research of [33]. fish farming education has a positive and significant effect on efficiency. [36] in [35] noted that the acquisition of skills and training of human resources can represent a source of competitive advantage for companies by enabling employees to be more efficient in the performance of tasks required in the process of manufacturing and marketing products [43]. Profit inefficiency can be reduced if the education level of the head of the household increases. actively attend training and learn experiences about hybrid rice production.

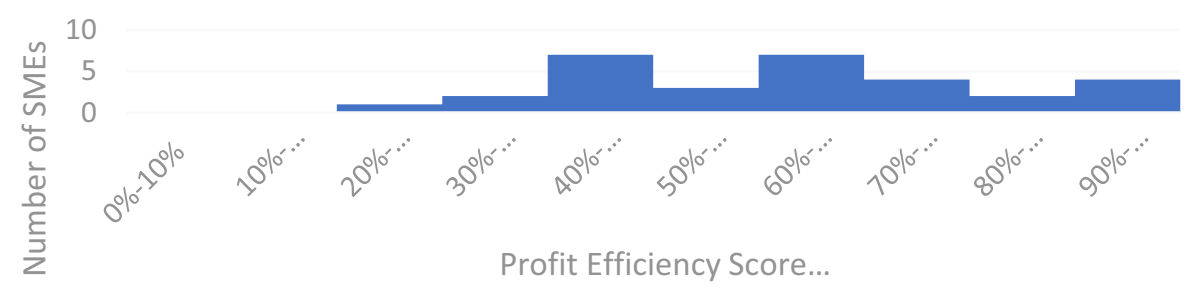

Fig. 1. Level of Profit Efficiency.

The results show that the smoked fish business MSMEs in Tambaksari Village are mostly in the range of $40 \%-50 \%$ and $60 \%-70 \%$ with an average profit efficiency value of 
$63 \%$. It implies that there is a profit inefficiency of $37 \%$ or the maximum potential profit of $37 \%$ is lost due to inefficiency.

\subsection{Tambaksari BUMDes Development Stragegy}

In determining the MSME development strategy through BUMDes in Kendal Regency, AHP (Analytic Hierarchy Process) is used. Data obtained from in-depth interview Keyperson. The results of the in-depth interview with the key person prioritized criteria were Human Resources (0.529), Institutional (0.202), Production (0.128), Capital (0.081), and Marketing (0.06).

Table 2. Weighting of criteria and sub criteria.

\begin{tabular}{|c|c|c|c|c|}
\hline Criteria & $\begin{array}{c}\text { Weighting } \\
\text { Criteria }\end{array}$ & Sub-Criteria & $\begin{array}{c}\text { Weighting } \\
\text { of Sub- } \\
\text { Criteria }\end{array}$ & $\begin{array}{c}\text { Final } \\
\text { Weighting }\end{array}$ \\
\hline \multirow[t]{4}{*}{ Marketing } & \multirow[t]{4}{*}{0.060} & Promotion & 0.288 & 0.017 \\
\hline & & Third party cooperation & 0.289 & 0.017 \\
\hline & & e-commerce & 0.086 & 0.005 \\
\hline & & MSME centre & 0.336 & 0.020 \\
\hline \multirow[t]{4}{*}{ Capital } & \multirow[t]{4}{*}{0.081} & Credit facility & 0.470 & 0.038 \\
\hline & & Without collateral & 0.343 & 0.028 \\
\hline & & Periodic finance report & 0.083 & 0.007 \\
\hline & & Segregation of account & 0.103 & 0.008 \\
\hline \multirow[t]{4}{*}{ Production } & \multirow[t]{4}{*}{0.128} & QC & 0.465 & 0.060 \\
\hline & & Permission & 0.117 & 0.015 \\
\hline & & Technology & 0.323 & 0.041 \\
\hline & & SOP & 0.096 & 0.012 \\
\hline \multirow[t]{4}{*}{ Instituional } & \multirow[t]{4}{*}{0.202} & Increasing the role of BUMDes & 0.344 & 0.069 \\
\hline & & Stakeholder coordination & 0.471 & 0.095 \\
\hline & & Create coperative & 0.089 & 0.018 \\
\hline & & Ease of permission & 0.096 & 0.019 \\
\hline \multirow[t]{4}{*}{ HRM } & \multirow[t]{4}{*}{0.529} & Managerial training & 0.467 & 0.247 \\
\hline & & Comparative study & 0.370 & 0.196 \\
\hline & & Incentives & 0.073 & 0.038 \\
\hline & & Periodic upgrades & 0.091 & 0.048 \\
\hline
\end{tabular}

The results show that the human resource aspect is the main priority aspect in the development of BUMDes because humans are the most important element in the development of an institution. In addition, the role of an organization and how the direction of organizational development will depend on the ability of the human resources who are members of the organization. Thus, the implementation of managerial training is very necessary for the development of human resources in BUMDes. Moreover, the second priority strategy in developing BUMDes is the importance of comparative studies. Comparative study activities with fish processing industry clusters in other areas will increase their knowledge of smoked fish processing, which can be used as a reference so 
that the processing carried out by members is more efficient. Then the third priority strategy is coordination between stakeholders. In developing BUMDes, it is not only the government that intervenes, but it is necessary to involve related parties, such as managers, the business environment, and the community, cooperation of each party is needed.

\section{Conclusion}

The efficiency of the smoked fish business MSMEs Tambaksari Village in Kendal Regency is still low because the average efficiency is $63 \%$. So there is still a potential profit of $37 \%$, which is lost due to inefficiency. The age and education of human resources significantly affect the inefficiency of MSMEs. Increasing age will increase the value of MSME inefficiency, while increasing education will reduce the value of inefficiency. Moreover, improving education and training for MSMEs is a solution for these two variables. On the other hand, education and training continue to be carried out as they get older or more experienced in running their business. Then, the proposed strategy for developing BUMDes Tambaksari based on results is managerial training, comparative studies and coordination with stakeholders in improving the performance of BUMDes Tambaksari. This gives managerial implications for the key persons to improve the performance of BUMDes in order to develop smoked fish business MSMEs in Tambaksari Village, Kendal.

\section{References}

1. A. Abdulai, W. E. Huffman, An examination of profit inefficiency of rice farmers in Northern Ghana (1998)

2. A. A. Adesina, K. K. Djato, Farm size, relative efficiency and agrarian policy in Cote d'Ivoire: profit function analysis of rice farms, Agricultural Economics, 14(2), 93-102 (1996)

3. D. Aigner, C. K. Lovell, P. Schmidt, Formulation and estimation of stochastic frontier production function models, Journal of econometrics, 6(1), 21-37 (1977)

4. A. I. Ajibefun, A. G. Daramola, Efficiency of microenterprises in the Nigerian economy, African Economic Research Consortium, Research Paper 134 (2003)

5. F. Ali, A. Parikh, M. Shah, Measurement of profit efficiency using behavioural and stochastic frontier approaches, Applied Economics, 26(2), 181-188 (1994)

6. M. Ali, , J. C. Flinn, Profit efficiency among Basmati rice producers in Pakistan Punjab, American journal of agricultural economics, 71(2), 303-310 (1989)

7. A. Aligori, Efisiensi Produksi Usaha Garam Rakyat di Kabupaten Indramayu, Doctoral dissertation, Tesis Sekolah Pascasarjana, Institut Pertanian Bogor (2013).

8. R. Alvarez, G. Crespi, Determinants of technical efficiency in small firms, Small business economics, 20(3), 233-244 (2003)

9. A. Akhigbe, J. McNulty, Profit efficiency sources and differences among small and large US commercial banks, Journal of Economics and Finance, 29(3), 289-299 (2005)

10. S. Bahta, D. Baker, Determinants of profit efficiency among smallholder beef producers in Botswana, International Food and Agribusiness Management Review, 18, 107-130 (2015)

11. R. Baker, A. Charnes, W. Cooper, Some models for estimating technical and scale inefficiencies in data envelopment analysis, Management Science, 30(9), 1078-1092 (1984) 
12. Bank of Indonesia, Profil bisnis usaha mikro, kecil dan menengah (UMKM), Kerjasama Lembaga Pengembangan Perbankan Indonesia (LPPI) dengan Bank Indonesia (2015).

13. W. J. Barchue, J. Aikaeli, Efficiency of Small and Medium-Sized Enterprises in Liberia: The Case of Monrovia, Business Management Review, 18(2) (2016)

14. A. N. Berger, L. J. Mester, Inside the black box: What explains differences in the efficiencies of financial institutions?, Journal of banking \& finance, 21(7), 895-947 (1997)

15. T. Biggs, Is small beautiful and worthy of subsidy? Literature review, International Finance Corporation (IFC), Washington, DC (2002).

16. J. W. Bos, M. Koetter, Handling losses in translog profit models, Applied Economics, 43(3), 307-312 (2011)

17. R. G. Chambers, Y. Chung, R. Färe, Profit, directional distance functions, and Nerlovian efficiency, Journal of optimization theory and applications, 98(2), 351-364 (1998)

18. T. Charoenrat, C. Harvie, The efficiency of SMEs in Thai manufacturing: A stochastic frontier analysis, Economic Modelling, 43, 372-393 (2014)

19. T. J. Coelli, D. P. Rao, G. E. Battese, An introduction to efficiency and productivity analysis, Dordrecht, Kluwer Academic Publishers The Netherlands (1998)

20. K. B. Cyree, W. P. Spurlin, The effects of big-bank presence on the profit efficiency of small banks in rural markets, Journal of Banking \& Finance, 36(9), 2593-2603 (2012)

21. T. Fitzpatrick, K. McQuinn, Measuring bank profit efficiency, Applied Financial Economics, 18(1), 1-8 (2008)

22. F. Galawat, M. Yabe, Profit efficiency in rice production in Brunei Darussalam: A stochastic frontier approach, J. ISSAAS, 18(1), 100-112 (2012)

23. T. S. Hyuha, Analysis of Profit Efficiency in Rice Production in Eastern and Northern Uganda. A Ph.D. Diss. Department of Agricultural Economics and Agribusiness Makerere University, Uganda 146 (2006)

24. T. S. Hyuha, B. Bashaasha, E. Nkonya, D. Kraybill, Analysis of profit inefficiency in rice production in Eastern and Northern Uganda, African Crop Science Journal, 15(4) (2007).

25. Kementerian Koperasi dan UKM RI, Data UMKM (2018)

26. O. Kolawole, Determinants of profit efficiency among small scale rice farmers in Nigeria: A profit function approach (No. 1004-2016-78920) (2006)

27. B. Kotey, C. J. O'Donnell, Data envelopment analysis in small and medium enterprises: A study of the Australian food, beverages and tobacco manufacturing industry, Small Enterprise Research, 10(2), 3-22 (2002)

28. T. Kuosmanen, M. Kortelainen, T. Sipiläinen, L. Cherchye, Firm and industry level profit efficiency analysis using absolute and uniform shadow prices, European Journal of Operational Research, 202(2), 584-594 (2010)

29. V. Le, C. Harvie, Firm performance in Vietnam: evidence from manufacturing small and medium enterprises, Department of Economics, University of Wollongong, Working Paper, 04-10 (2010)

30. M. Nerlove, Estimation and Identification of Cobb-Douglas Production Functions, Rand McNally, Chicago, Illinois (1965) 
31. I. N. Nwachukwu, C. Onyenweaku, Economic efficiency of Fadama Telfairia production in Imo State Nigeria: A translog profit function approach (2007)

32. K. Ogundari, Determinants of profit efficiency among small scale rice farmers in Nigeria. A profit function approach. Research Journal of Applied Sciences, 1(1-4), 116-122 (2006)

33. E. E. Onumah, J. A. Onumah, G. E. Onumah, Production risk and technical efficiency of fish farms in Ghana, Aquaculture, 495, 55-61(2018)

34. L. T. Ogunniyi, Profit efficiency among maize producers in Oyo state, Nigeria, ARPN J. Agric. Biol. Sci, 6, 11-17 (2011)

35. P. G. Pilar, A. P. Marta, A. Antonio, Profit efficiency and its determinants in small and medium-sized enterprises in Spain, BRQ Business Research Quarterly, 21(4), 238-250 (2018)

36. M. E. Porter, Ventaja Competitiva, Creación y Sostenimiento de un Desempẽ no Co, Editorial Continental, SA de CV México DF (1987)

37. S. Rahman, Profit efficiency among Bangladeshi rice farmers, Food policy, 28(5-6), 487-503 (2003)

38. R. Rismawati, Peranan Badan Usaha Milik Desa (BUMDES) Perwitasari dalam upaya meningkatkan perekonomian masyarakat minapolitan Desa Tambaksari Kecamatan Rowosari Kabupaten Kendal, Doctoral dissertation, UIN Walisongo (2018)

39. T. L. Saaty, How to make a decision: the analytic hierarchy process, European journal of operational research, 48(1), 9-26 (1990)

40. T. L. Saaty, How to make a decision: the analytic hierarchy process, Interfaces, 24(6), 19-43 (1994)

41. Sudaryanto, Strategi Pemberdayaan UMKM Menghadapi Pasar Bebas ASEAN, Jurnal Ekonomi Akuntansi Dan Manajemen, 1(2) (2012)

42. T. B. Tran, R. Q. Grafton, T. Kompas, Firm efficiency in a transitional economy: Evidence from Vietnam, Asian Economic Journal, 22(1), 47-66 (2008)

43. P. H. Trong, O. Napasintuwong, Profit inefficiency among hybrid rice farmers in central Vietnam, Agriculture and Agricultural Science Procedia, 5, 89-95 (2015)

44. R. E. Werdani, N. I. Kurniawati, J. B. Sukoco, A. Windriya, D. Iskandar, Pelatihan Pemasaran Produk Homemade Melalui Sosial Media, JPPM (Jurnal Pengabdian Dan Pemberdayaan Masyarakat), 4(1), 1 (2020) 